\title{
PKM KELOMPOK USAHA KERIPIK TEMPE DI DESA TULUNGREJO, KECAMATAN BUMIAJI DAN DESA BEJI, KECAMATAN JUNREJO, KOTA BATU, JAWA TIMUR
}

\author{
PKM Tempe Chips Business Group at Junrejo, Batu \\ Panji Deoranto ${ }^{1}$ dan Retno Astuti ${ }^{1}$ \\ Jurusan Teknologi Industri Pertanian \\ Fakultas Teknologi Pertanian - Universitas Brawijaya \\ Jl. Veteran, Malang
}

\begin{abstract}
ABSTRAK
Malang Raya termasuk Kota Batu merupakan daerah penghasil tempe dengan karakteristik tempe yang khas yaitu teksturnya yang padat. Karakteristik tempe yang khas tersebut telah mendorong banyak industri kecil dan rumah tangga yang memproduksi keripik tempe. Kota Batu yang merupakan kota wisata dengan keripik tempe sebagai oleh-oleh utama, membuat permintaan akan keripik tempe sangat tinggi sehingga pasar untuk produk ini selalu ada. Kondisi ini yang mendorong 2 UKM memproduksi keripik tempe yaitu UKM Keripik Tempe "Fauzi" (Mitra 1) dan UKM Keripik Tempe "Ibu Anah" (Mitra 2). Proses produksi yang masih dilakukan secara manual dan menggunakan peralatan skala rumah tangga oleh UKM Keripik Tempe "Fauzi" dan UKM Keripik Tempe "Ibu Anah" menyebabkan hasil produksi kurang maksimal. Permasalahan Mitra 1 (UKM Keripik Tempe "Fauzi") adalah perajang tempe yang digunakan masih perajang tempe manual. Permasalahan pada Mitra 2 (UKM Keripik Tempe "Ibu Anah") adalah perajangan masih menggunakan pasrah kayu, proses pengemasan masih menggunakan hand sealer yang sudah mulai rusak, dan proses pengupasan dan pemecahan kedelai pada pembuatan tempe mentah masih menggunakan mesin pengupas sederhana rakitan sendiri. Masalah manajemen dan sanitasi juga menjadi masalah di kedua UKM. Metode pelaksanaan program di kedua mitra antara lain peningkatan efisiensi dan kapasitas pengupasan dan pemecahan kedelai Mitra 2, peningkatan kapasitas perajangan di Mitra 1, peningkatan efisiensi pengemasan di mitra 2, perbaikan manajemen keuangan dan pemasaran di kedua mitra, dan pendampingan penerapan cara-cara produksi pangan yang baik di kedua mitra. Tim juga akan membantu kedua mitra dengan perbaikan sanitasi serta pendampingan dalam penyusunan dan penerapan SSOP di kedua mitra.

Kata kunci: tempe, keripik tempe, sanitation operating procedur (SSOP)
\end{abstract}

\section{ABSTRACT}

Malang, including Batu City, is a tempe-producing region with a characteristic tempe which is a dense texture. The characteristics of the typical tempe have encouraged many small industries and households that produce tempe chips. Batu City which is a tourist city with tempe chips as the main gift, makes the demand for tempe chips very high so that the market for this product is always there. This condition encourages 2 SMEs to produce tempe chips, namely "Fauzi" Tempe Chips (Mitra 1) and "Ibu Anah" UKM Tempe Chips (Mitra 2). The production process that is still done manually and using household-scale equipment by UKM Fauzi Tempe Chips and UKM Ibu Tempe causes less than optimal 
production results. The Problem of Mitra 1 (SME Tempe Chips "Fauzi") is the tempe chopper used is still tempe manual chopper. Problems with Mitra 2 (UKM "Tempa Chips" Ibu Anah ") are still using wooden handicrafts, the packaging process still uses hand sealers which have started to break, and the process of stripping and breaking soybeans in raw tempeh is still using a simple self-assembling machine. Management and sanitation issues are also a problem in both SMEs. The program implementation methods at both partners include increasing efficiency and capacity of Mitra 2 soybean stripping and solving, enhancing the capacity of cranes in Mitra 1, increasing packaging efficiency in partner 2, improving financial and marketing management in both partners, and assisting in the implementation of food production methods good in both partners. The team will also assist both partners with improved sanitation and assistance in the preparation and implementation of SSOP in both partners.

Keywords: tempe, tempe chips, sanitation operating procedure (SSOP)

\section{PENDAHULUAN}

Tempe merupakan makanan khas Indonesia yang banyak mengandung khasiat. Tempe mengandung isoflavon dalam kadar tinggi yang berperan seperti esterogen sehingga penting sebagai pangan fungsional untuk wanita terutama yang sudah menopause (Nakajima et al., 2005). Tempe mengandung antioksidan yang berkhasiat terhadap kesehatan (Esaki et al., 1996) serta mempunyai peran mencegah dan mengobati berbagai penyakit (Karyadi dan Lukito, 1996). Tempe merupakan sumber protein yang murah bagi masyarakat.

Malang Raya termasuk Kota Batu merupakan daerah penghasil tempe dengan karakteristrik tempe yang khas yaitu teksturnya yang lebih kompak dibandingkan tempe dari wilayah lain. Hal ini menyebabkan tempe yang dihasilkan di wilayah Malang Raya jika dibuat keripik tempe dapat dibuat keripik tempe dengan irisan tipis sehingga renyah dan enak. Karakteristik tempe yang khas tersebut telah mendorong banyak industri kecil dan rumah tangga yang memproduksi keripik tempe. Akan tetapi permintaan akan keripik tempe sangat tinggi sehingga pasar untuk produk ini selalu ada. Permintaan yang tinggi tersebut karena Malang Raya terutama Kota Batu merupakan kota wisata dengan keripik tempe sebagai oleh-oleh utama. Kondisi ini yang mendorong 2 UKM memproduksi keripik tempe dan olahan sejenis yaitu UKM Keripik Tempe "Fauzi" (Mitra 1) dan UKM Keripik Tempe "Ibu Anah" (Mitra 2).

Selama ini proses produksi pada kedua UKM dilakukan secara manual dengan alat produksi skala rumah tangga kedua. Proses pengadonan juga masih manual menggunakan tangan dalam ember berkapasitas 7,5 L. Akibatnya seringkali adonan tidak homogen dan memerlukan waktu lama. Perajang tempe pada Mitra 1 masih manual menyebabkan perajangan tidak aman karena beresiko tangan pekerja terpotong. Kemasan plastik yang digunakan Mitra 1 sudah baik yaitu menggunakan plastik poliprolpilen $0,8 \mathrm{~mm}$. Hanya saja label yang digunakan merupakan kertas sablon tahan minyak yang dimasukkan ke dalam kemasan. Mitra tidak menggunakan label stiker karena harganya yang mahal. Hal ini menyebabkan seringkali label terkena minyak dan berbekas.

Perajangan di Mitra 2 UKM Ibu Anah menggunakan pasrah kayu sehingga proses lama. Untuk perajangan $5 \mathrm{~kg}$ tempe dibutuhkan waktu sekitar 2 jam. Proses pengemasan di Mitra 2 masih menggunakan hand sealer yang sudah mulai rusak sehingga seringkali tidak rapat. Permasalahan lain adalah proses pengupasan dan pemecahan kedelai pada pembuatan tempe mentah di UKM "Ibu Anah" menggunakan mesin 
pengupas sederhana rakitan sendiri. Karena rakitan sendiri dan sudah lama sehingga seringkali kedelai tidak terkelupas dan tidak terbelah. Hal ini menyebabkan cacat pada proses fermentasi akibat bagian kedelai yang tidak terkelupas kulit arinya dan tidak terbelah tdiak bisa ditembus oleh hifa dari kapang tempe. Perbaikan proses pengupasan dan pemecahan kedelai menjadi krusial bagi Mitra 2.

Masalah manajemen juga menjadi masalah di kedua UKM. Manajemen yang tidak tertata menyebabkan kedua UKM tidak tahu persis berapa marjin keuntungan yang mereka peroleh. Keduanya belum menerapkan sistem pembukuan keuangan yang baik. Manajemen pemasaran juga menjadi masalah karena belum ada sistem pemasaran yang terstruktur dan pekerja khusus untuk pemasaran. Tenaga pemasaran di UKM Fauzi hanya bertugas mengantar barang dan bukan mencari pasar. Pemasaran di UKM Ibu Anah hanya mengandalkan pesanan dari pengepul. Pengepul kemudian melakukan pengemasan (repacking) dengan kemasan bermerek lain sehingga nilai tambah (marjin) terbesar ada di tangan pengepul tersebut. Inisiasi produk keripik tempe dalam kemasan perlu dilakukan oleh mitra dengan difasilitasi pengemas hand sealer.

Permasalahan lain yang krusial adalah permasalahan sanitasi terutama di Mitra 2. Terlihat bahwa proses di Mitra 2 kurang bersih yaitu banyak bahan yang berceceran dan peralatan produksi yang terlihat kurang bersih. Sanitasi pekerja di Mitra 1 sudah baik yaitu pekerja menggunakan tutup kepala, sarung tangan, dan masker. Hanya saja pengetahuan mitra tentang sanitasi bahan masih terbatas terlihat bahwa peletakkan produk jadi di dekat bahan mentah yang belum diproses. Oleh karena itu perlu ada upaya pendampingan mitra untuk penerapan cara-cara produksi pangan yang baik secara sederhana.

\section{METODE PELAKSANAAN \\ 1. Peningkatan efisiensi dan kapasitas pengupasan dan pemecahan kedelai Mitra 2}

Pengupasan kedelai di Mitra 2 dilakukan dengan menggunakan mesin pengupas dan pemecah kedelai sederhana rakitan sendiri (Gambar 4). Mesin tersebut sudah lama dipakai sejak usaha ini berdiri pada tahun 2000. Kinerja mesin tersebut telah mengalami penurunan sehingga seringkali terjadi cacat yaitu kedelai tidak terkupas dan terbelah. Akibatnya adalah proses fermentasi tidak sempurna karena hifa kapang tidak bisa menembus kedelai utuh. Hal ini menyebabkan tempe menjadi keras dan sulit untuk diiris. Untuk mengatasi masalah ini, melalui PKM akan dilakukan fasilitasi mesin pengupas dan pemecah kedelai seperti ditunjukkan Gambar 5. Melalui mesin tersebut, diharapkan proses pengupasan dan pemecahan sempurna sehingga tidak terjadi cacat pada tempe yang dihasilkan.

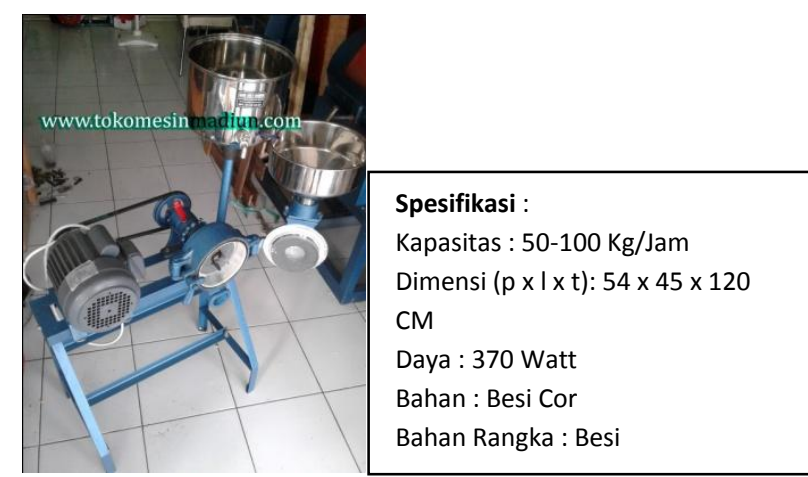

Gambar 5. Mesin pengupas dan pemecah kedelai

\section{Peningkatan Kapasitas Perajangan di Mitra 1}

Perajangan yang di Mitra 1 menggunakan mesin perajang terbuka yang kurang aman bagi keselamatan kerja. Mitra 1 menginginkan proses perajangan yang aman dan lebih cepat sehingga diperlukan mesin perajang tempe seperti ditunjukkan Gambar 7 . Mitra 2 masih melakukan proses perajangan menggunakan pasrah kayu secara manual. Walaupun ada resiko tangan tersayat, tetapi 
Mitra 2 tidak menganggap hal tersebut menjadi masalah karena prioritas solusi yang harus diselesaikan adalah pengupasan dan pemecahan biji kedelai. Oleh karena itu, fasilitasi mesin perajang tempe hanya akan dilakukan di Mitra 1.

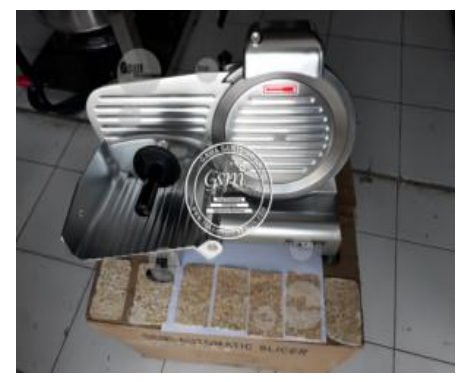

Spesifikasi : type : 220 ES / B-8 dimensi : 45 x 28 x 32 $\mathrm{cm}$ diameter pisau : 22 $\mathrm{cm}$ daya listrik : 120 watt 220v/1P Berat mesin : $13.2 \mathrm{~kg}$

Gambar 7. Mesin perajang tempe

\section{Peningkatan Efisiensi Pengemasan di Mitra 2}

Pengemasan keripik tempe di Mitra 2 terkendala masaalah hand sealer yang digunakan sudah mulai rusak. Akibatnya seringkali proses pengemasan menjadi tidak sempurna yaitu kemasan tidak rapat akibat hand sealer kurang panas. Berhubung Mitra 2 menjual keripik tempe dalam kemasan, proses pnegemasan ini sangat krusial. Untuk meningkatkan efisiensi pengemasan, penggunaan kemasan vertikal semi otomatis (Gambar 8)a akan sangat membantu Mitra 2.

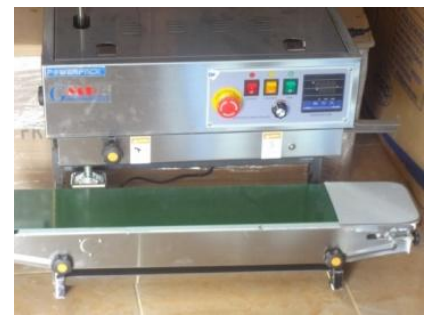

Gambar 8. Mesin pengemas vertikal semi otomatis

Melalui program ini, Mitra 2 akan mulai melakukan penjajagan pasar untuk keripik tempe dalam kemasan. Selama ini mitra menjual keripik secara curah ke pengepul. Proses pengemasan dilakukan oleh pengepul sehingga marjin keuntungan yang tinggi malah di pihak pengepul. Oleh karena itu, pengemasan menjadi penting untuk penjajagan pasar. Penggunaan pengemas vertical semi otomatis (Gambar 8) merupakan fasilitas yang diperlukan untuk pengemasan keripik tempe di Mitra 2 untuk penjajagan pasar keripik tempe kemasan

\section{Perbaikan Manajemen Keuangan dan Pemasaran di Kedua Mitra}

Masalah manajemen juga menjadi masalah di kedua UKM. Manajemen yang tidak tertata menyebabkan kedua UKM tidak tahu persis berapa marjin keuntungan yang mereka peroleh. Keduanya belum menerapkan sistem pembukuan keuangan yang baik.

Manajemen pemasaran juga menjadi masalah karena belum ada sistem pemasaran yang terstruktur dan pekerja khusus untuk pemasaran. Tenaga pemasaran di UKM Fauzi hanya bertugas mengantar barang dan bukan mencari pasar. Pemasaran di UKM Ibu Anah hanya mengandalkan pesanan dari pengepul.

Pendampingan penataan manajemen usaha akan dilakukan di kedua UKM. Pengenalan pembukuaan keuangan sederhana termasuk perhitungan kelayakan ekonomi akan disampaikan kepada kedua UKM. Demikian pula manajemen pemasaran dan langkah-langkah konkrit yang harus dilakukan akan diberikan selama pendampingan. Mitra akan didampingi dalam pembinaan tenaga pemasaran khusus.

\section{Pendampingan Penerapan Cara-cara Produksi Pangan yang Baik di Kedua Mitra}

Permasalahan lain yang krusial adalah permasalahan sanitasi terutama di Mitra 2. Terlihat bahwa proses di Mitra 2 kurang bersih yaitu banyak bahan yang berceceran dan peralatan produksi yang terlihat kurang bersih. Sanitasi pekerja di Mitra 1 sudah baik yaitu pekerja menggunakan tutup kepala, sarung tangan, dan masker. Hanya saja pengetahuan mitra tentang sanitasi bahan 
masih terbatas terlihat bahwa peletakkan produk jadi di dekat bahan mentah yang belum diproses. Oleh karena itu perlu ada upaya pendampingan mitra untuk penerapan cara-cara produksi pangan yang baik secara sederhana.

Salah satu target yang harus dicapai melalui program PKM ini adalah peningkatkan sanitasi pada proses produksi keripik tempe di kedua mitra. Perbaikan sanitasi dapat dicapai salah satunya dengan penyusunan SSOP untuk pekerja, lingkungan, dan peralatan. SSOP yang sudah disusun tersebut harus disosialisasikan karena kedua mitra harus mempunyai pemahaman yang baik tentang pentingnya sanitasi. Selanjutnya mitra perlu didampingi untuk implementasi SSOP yang sudah disusun. Implementasi SSOP harus dilakukan di kedua mitra sehingga proses produk lebih higienis.

\section{HASIL DAN LUARAN CAPAIAN}

\section{pengupasan dan pemecahan kedelai Mitra 2}

Pengupasan kedelai di Mitra 2 dilakukan dengan menggunakan mesin pengupas dan pemecah kedelai sederhana rakitan sendiri (Gambar 4). Mesin tersebut sudah lama dipakai sejak usaha ini berdiri pada tahun 2000. Kinerja mesin tersebut telah mengalami penurunan sehingga seringkali terjadi cacat yaitu kedelai tidak terkupas dan terbelah. Akibatnya adalah proses fermentasi tidak sempurna karena hifa kapang tidak bisa menembus kedelai utuh. Hal ini menyebabkan tempe menjadi keras dan sulit untuk diiris.

Fasilitasi mesin pengupas dan pemecah kedelai akan dilakukan melalui kegiatan ini. Proses pembuatan mesin tersebut dapat dilihat pada Gambar 9. Mesin tersebut sedang dalam tahap pembuatan dan sudah $70 \%$ selesai. Mesin pengupas dan pemecah kedelai tersbeut jika sudah jadi dapat dilihat pada Gambar 10.

\section{Peningkatan efisiensi dan kapasitas}

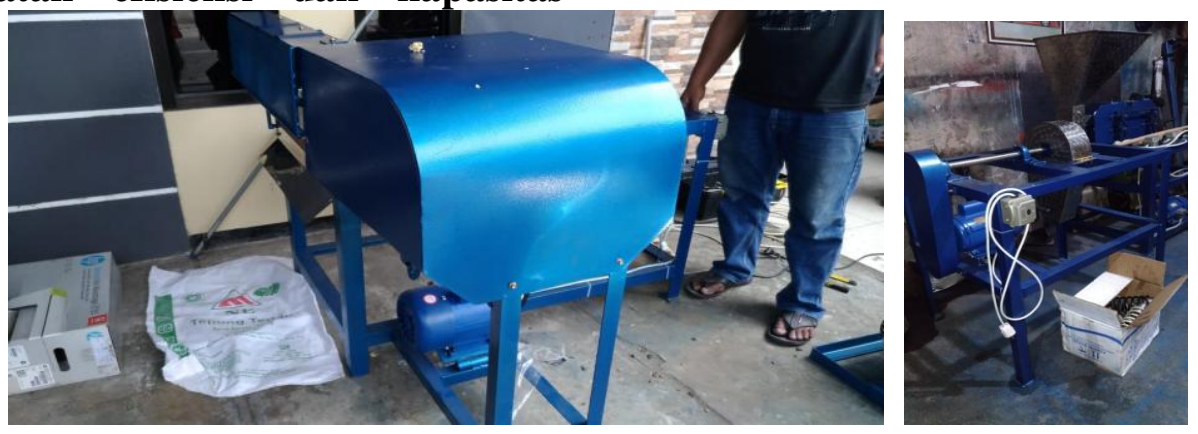

Gambar 9. Proses pembuatan mesin pengupas dan pemecah kedelai

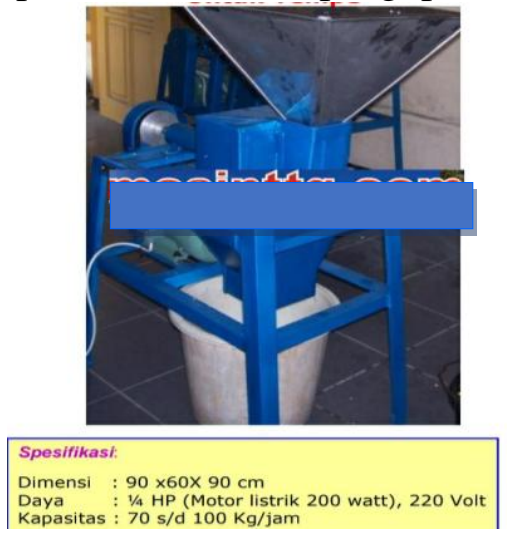

Gambar 10. Mesin pengupas dan pemecah kedelai 
Mesin tersebut mempunyai prinsip kerja mengupas kedelai setelah kedelai direndam. Prinsip pengupasan adalah rotasi sehingga kulit air terkelupas sekaligus kedelai pecah menjadi dua bagian. Kulit ari yang terkelupas kemudian dibuang melalui air yang dialirkan. Mesin ini mempunyai kapasitas $100 \mathrm{~kg} / \mathrm{jam}$ sehingga diharapkan dapat meningkatkan efisiensi produksi dan mutu tempe yang dihasilkan.

\section{Peningkatan Kapasitas Perajangan di Mitra 1}

Mitra 1 selama ini menggunakan mesin perajang terbuka yang kurang aman bagi keselamatan kerja. Mitra 1 menginginkan proses perajangan yang aman dan lebih cepat sehingga diperlukan mesin perajang tempe otomatis yang dapat merajang tempe beberapa batang sekaligus. Pada awalnya Mitra 1 akan difasilitasi mesin perajang tempe semi otomatis yang masih menggunakan tangan untuk mendorong tempe ke bagian pemotong alat. Berdasarkan hasil diskusi dengan Mitra 1, mitra 1 menginginkan mesin perajang tempe otomatis yang dapat merajang lonjoran tempe beberapa buah sekaligus. Proses pembuatan mesin tersebut dapat dilihat pada Gambar 11. Mesin tersebut sudah dicoba oleh Mitra 1 seperti ditunjukkan Gambar 12.
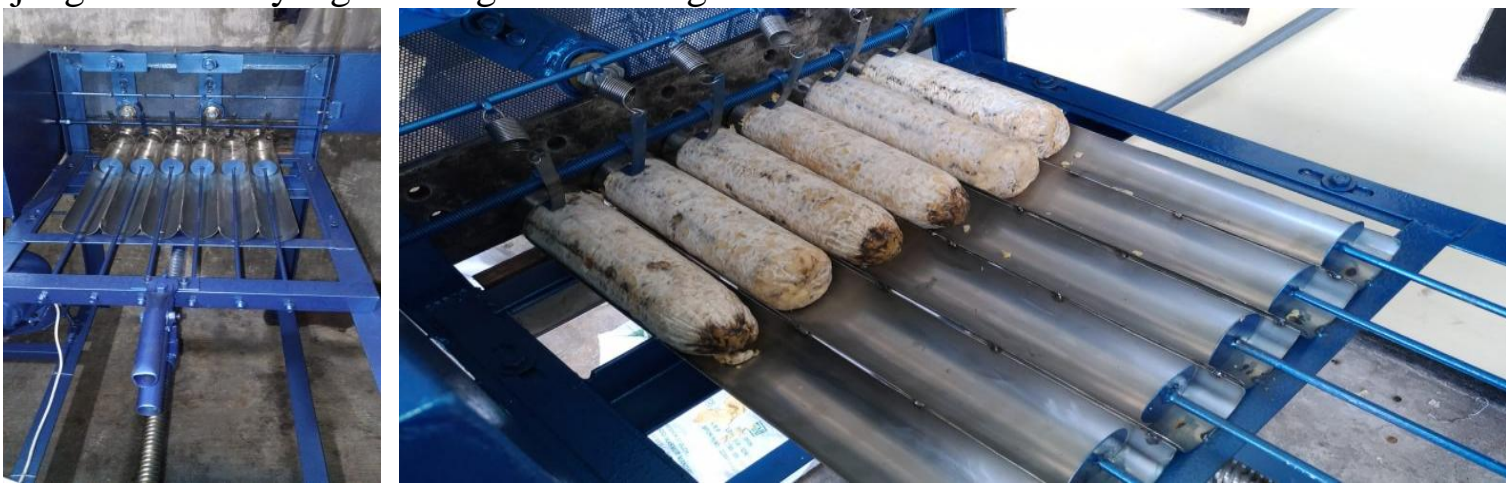

Gambar 11. Proses pembuatan mesin perajang tempe otomatis

Dengan adanya mesin perajang otomatis ini, proses perajangan tempa akan lebih efisien karena mesin bekerja secara otomatis tidak perlu bantuan tangan untuk mendorong tempe ke bagian pemotong. Selain itu, mesin ini aman karena lonjoran tempe akan secara otomatis terdorong ke arah pisau. Mesin ini juga dapat meningkatkan kapasitas produksi karena proses perajangan yang bisa lima lonjoran tempe sekaligus.

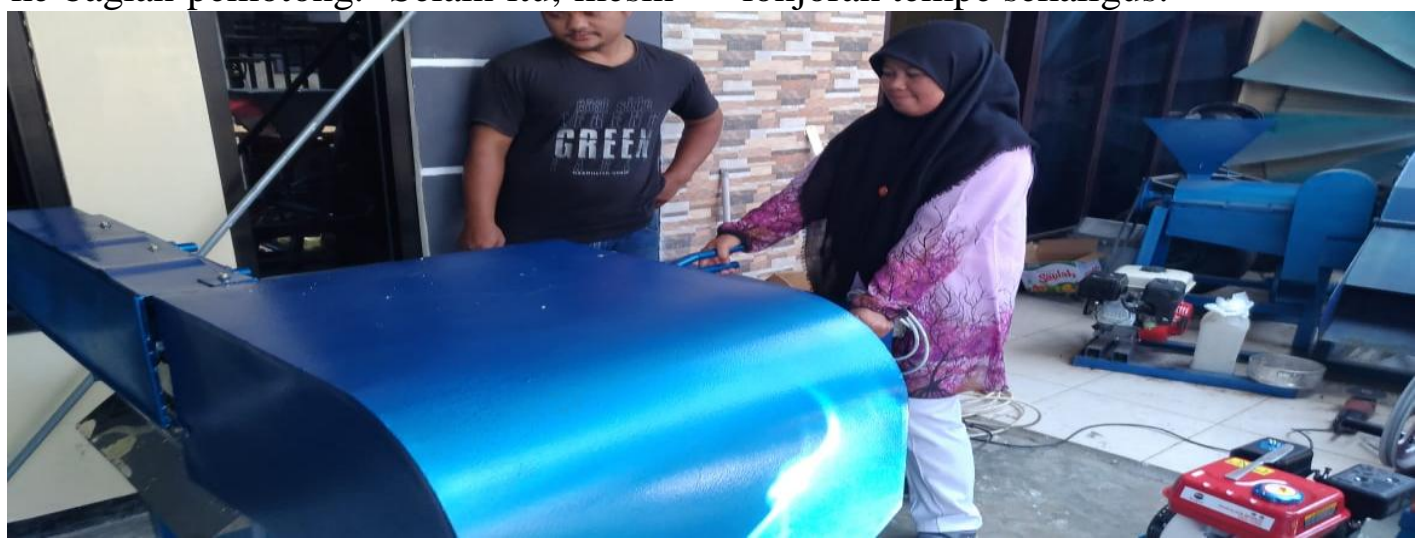

Gambar 12. Uji coba mesin perajang oleh Mitra 1 


\section{a. Peningkatan Efisiensi Pengemasan di Mitra 2}

Peningkatan efisiensi pengemasan di Mitra 2 akan dilakukan dengan fasilitasi mesin pengemas kontinyu tipe continuous band sealer. Mesin ini mempunyai suhu yang bisa diatur sehingga dapat digunakan untuk mengemas berbagai jenis dan ketebalan plastik walaupun disarankan Mitra 2 untuk menggunakan plastik tebal seperti PP 0,8 mm. Tim pelaksana sedang melakukan survei dan penjajagan untuk mesin pengemas tersebut. Mesin pengemas tersebut dapat dilihat pada Gambar 13.

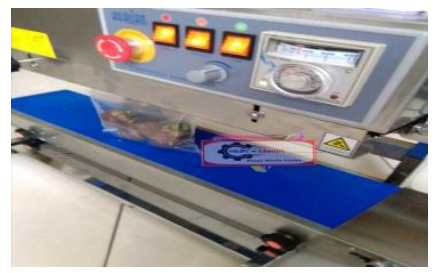

Gambar 13. Mesin pengemas kontinyu

\section{b. Perbaikan Manajemen Keuangan dan Pemasaran di Kedua Mitra}

Pengetahuan manajemen dan keteranpilan manajerial kedua mItra perlu ditingkatkan melalui pendampingan manajemen. Tim pelaksana kegiatan sudah mempersiapkan pendampingan penataan manajemen usaha di kedua UKM. Pendampingan meliputi pembukuaan keuangan sederhana dan perhitungan kelayakan ekonomi direncanakan untuk disampaikan kepada kedua UKM. Demikian pula manajemen pemasaran. Diskusi dengan kedua mitra sangat penting untuk mengetahui permasalahan riil yang dihadapi sehingga bisa dibantu penyelesaiannya.

\section{Pendampingan Penerapan Cara-cara Produksi Pangan yang Baik di Kedua Mitra}

Cara-cara pengolahan pangan yang baik (GMP, Good Manufacturing Practices) merupakan salah satu syarat produksi pangan sehingga layak dan aman untuk dikonsumsi.
Kedua mitra harus mengetahui syarat-syarat yang harus dipenuhi dalam GMP. Form penilaian GMP sudah disusun (Lampiran 1) dan akan segera disosialisasikan kepada kedua Mitra. Mitra diharapkan dapat melakukan self assessment dan melakukan koreksi diri. Mitra juga diharapkan dapat membuat rencana perbaikan dari hasil self assessment tersebut.

Salah satu target yang harus dicapai melalui program PKM ini adalah peningkatkan sanitasi pada proses produksi keripik tempe di kedua mitra. Perbaikan sanitasi dapat dicapai salah satunya dengan penyusunan SSOP untuk pekerja, lingkungan, dan peralatan. SSOP sudah disusun (Lampiran 2) dan akan disosialisasikan karena kedua mitra harus mempunyai pemahaman yang baik tentang pentingnya sanitasi. Selanjutnya mitra perlu didampingi untuk implementasi SSOP yang sudah disusun. Implementasi SSOP harus dilakukan di kedua mitra sehingga proses produk lebih higienis.

\section{Target Luaran}

Luaran yang ditargetkan untuk dihasilkan dari program PKM ini adalah kapasitas perajangan merupakan luaran yang ditargetkan untuk Mitra 1. Peningkatan kapasitas dan efisensi pengupasan kedelai serta pengemasan merupakan target untuk Mitra 2. Perbaikan manajemen akan dilakukan di kedua mitra.

Tabel 1. Luaran peningkatan kapasitas dan efisiensi produksi keripik tempe 
Tabel 1. Luaran peningkatan kapasitas dan efisiensi produksi keripik tempe

\begin{tabular}{|c|c|c|c|}
\hline \multirow[t]{2}{*}{ Proses } & & Sebelum Program PKM & Estimasi Setelah PKM \\
\hline & & Jumlah Waktu & Jumlah Waktu \\
\hline $\begin{array}{l}\text { Pengupasan } \\
\text { kedelai }\end{array}$ & Mitra 2 & $\begin{array}{l}\text { Pengupasan dan } \\
\text { pemecahan banyak yang } \\
\text { gagal }\end{array}$ & Tidak ada yang gagal \\
\hline Perajangan & Mitra 1 & $20 \mathrm{~kg}$ tempe $\quad 4 \mathrm{jam}$ & 1 jam \\
\hline Pengemasan & Mitra 2 & Tanpa kemasan & $\begin{array}{l}\text { Inisasi produk dalam } \\
\text { kemasan }\end{array}$ \\
\hline Manajemen & $\begin{array}{l}\text { Mitra } 1 \& \\
2\end{array}$ & $\begin{array}{l}\text { Manajemen pemasaran } \\
\text { dan keuangan belum } \\
\text { tertata }\end{array}$ & $\begin{array}{l}\text { Perbaikan manajemen } \\
\text { pemasaran dan keuangan }\end{array}$ \\
\hline
\end{tabular}

Bagi Tim Pelaksana, rencana target capaian luaran ditunjukkan Tabel 2. Target capaian luara melalui program PKM ini adalah publikasi pada jurnal nasional, perbaikan manajemen, peningkatan kapasitas produksi, dan mekanisasi proses produsi.

Tabel 2. Rencana target capaian luaran

\begin{tabular}{|c|c|c|}
\hline No. & Jenis Luaran & $\begin{array}{c}\text { Indikator } \\
\text { Capaian }\end{array}$ \\
\hline \multicolumn{3}{|c|}{ Luaran Wajib } \\
\hline 1. & $\begin{array}{l}\text { Publikasi ilmiah pada jurnal ber-ISSN/Prosiding jurnal } \\
\text { nasional }\end{array}$ & accepted \\
\hline 2. & Publikasi pada media cetak/online/repocitory PT & sudah terbit \\
\hline 3. & $\begin{array}{l}\text { Peningkatan daya saing (peningkatan kuantitas, kualitas, serta } \\
\text { nilai tambah barang, jasa, diversifikasi produk, atau sumber } \\
\text { daya lainnya }\end{array}$ & penerapan \\
\hline 4. & $\begin{array}{l}\text { Peningkatan penerapan iptek di masyarakat (mekanisasi, IT, } \\
\text { dan manajemen) }\end{array}$ & penerapan \\
\hline & $\begin{array}{l}\text { Perbaikan tata nilai masyarakat (seni budaya, sosial, politik, } \\
\text { keamanan, ketentraman, pendidikan, kesehatan) }\end{array}$ & tidak ada \\
\hline \multicolumn{3}{|c|}{ Luaran Tambahan } \\
\hline 1. & Publikasi jurnal internasional & tidak ada \\
\hline 2. & Jasa; rekayasa sosial, metode atau sistem, produk/barang & tidak ada \\
\hline & Inovasi baru, TTG & tidak ada \\
\hline & HKI & tidak ada \\
\hline & Buku ber-ISBN & tidak ada \\
\hline
\end{tabular}

\section{KESIMPULAN}

Dari hasil diskusi dengan mitra diketahui bahwa Mitra 1 membutuhkan alat perajang otomatis. Mitra 2 membutuhkan mesin pengupas dan oemecah kedelai, serta mesin pengemas kontinyu. Semua peralatan tersebuit dalam tahap pemesanan dan setelah selesai dibuat akan segara dilakukan pendampingan serta evaluasi dan monitoring dampak fasilitasi tersebut. Pelatihan manajemen sudah dipersiapkan oleh tim dan akan segera dilaksanakan. Demikian pula tim sudah menyiapakn form GMP dan panduan 
SSOP yang sidap disosialisasikan kepada kedua mitra.

\section{DAFTAR PUSTAKA}

Esaki, H., $\underline{\text { H. Onozaki, }}$ S. Kawakishi, T. Osawa. (1996). New Antioxidant Isolated from Tempeh. J. Agric. Food Chem. 44(3): 696-700. DOI: $10.1021 /$ jf950454t
Karyadi, D., W. Lukito. (1996). Beneficial Effects of Tempeh in Disease Prevention and Treatment. Nutritiuon Reviews 54(11): S94-S98.

Nakajima, N., N. Nozaki, K. Ishihara, A. Ishikawa, H. Tsuji. (2005). Analysis of Isoflavone Content in Tempeh, A Fermented Soybean, and Preparation of A New Isoflavone-Enriched Tempeh. $J$. Biosci. Bioeng. 100(6): 685-687. Doi: 10.1263/Jbb.100.685 